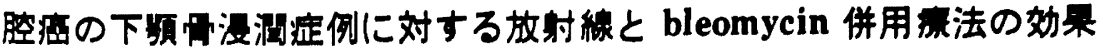

\author{
岡本学・大関悟・颣口勝規・田代英蜼
}

\section{The effects of combined treatment with radiation and bleomycin on the oral carcinoma involving the mandible}

\author{
Manabu Oкамото - Satoru Ozeki - Yoshinori HiguchI \\ Hideo TASHIRO
}

\begin{abstract}
The effect of concurrent combined treatment with $22.5 \mathrm{~Gy}$ of radiation and $110 \mathrm{mg}$ of bleomycin or $55 \mathrm{mg}$ of peplomycin on oral carcinoma involving the mandible was examined histologically.

In 14 of 18 patients who had mandibles resected after this combined treatment, bone invasion by carcinoma was observed histologically. According to Shimosato's classification of histological effects, 3 belonged to Grade II / IV, 4 to II b, 3 to II a and 4 to I. The formation of new bone that was considered to be reparable was observed in the marked effective patients.

In 4 patients the Grade II $\mathrm{b}$, residual surviving cancer cells were observed in the mandible.

Accordingly, excision was needed in the area of radiologic features of mandibular infiltration. But it is considered that although the excision scope for the patient who has received the preoperative treatment is the same as that for the patient who has not, it is advantageous for the former patient that a wider safety region is obtained.
\end{abstract}

Key words: oral carcinoma involving mandible, combined treatment with radiation and bleomycin, histological effects

緒

\section{言}

口腔癌は，その進展に伴い下額骨に浸潤することが多 く ${ }^{1 \sim 3)}$, そのような症例の治療は, 放射線療法や化学療 法たけでは奻果が乏しいことや放射線骨髄炎の発症を考 麀し，従来より広範囲の切除を行らことが主体となって いる4 9). したがって，切除後の機能的ならびに害美的 な障害は重要な課題である. 当科では, これらの問題を 改善すへく，局所制御成績の向上と切除範囲の縮小を目 的として, 放射線と bleomycin (以下 BLM と略す) あ るいは peplomycin (以下 PEP と略す) の同時併用療法 を術前治療として行っている，その治療成縜について，

九州大学楼学部口腔外科学第 1 講座

（主任：田代英雄教授）

First Department of Oral Surgery, Faculty of Dentistry, Kyushu University. (Chief: Prof, Hideo Tashiro)

受付日：昭和 63 年 2 月 17 日

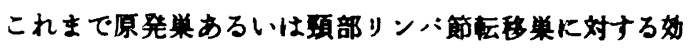

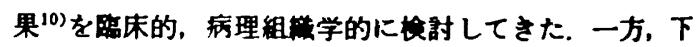

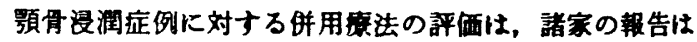

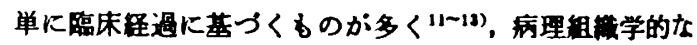
覞点から群細に娭討した報告は少ない，そこで今回，併 用度法の奻果について，下頻骨切除例の大洁切片により 病理組織学的に恰索し, 本治㢈法の有用性ならびに㭪前 治療としての意義について娭討を行った。

\section{対象症例と検案方法}

1976年 1 月より1985年12月までの10年間に，九州大学 齿学部附属病院口院外科で, ${ }^{\circ 0} \mathrm{Co}$ 外照射と BLM ある いはPEP の同時併用㴔法を施行した口腔粘膜扁平上皮

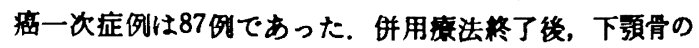
一部を含めて原発巣切除を行った在例は20例で，このら ち切除した下頻骨の病理組䋍学的な検索を行った 18 例

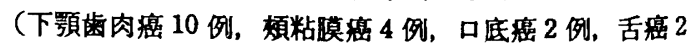
例）を対象とした. 1978年 UICC 分類 ${ }^{44}$ に基つく T分 


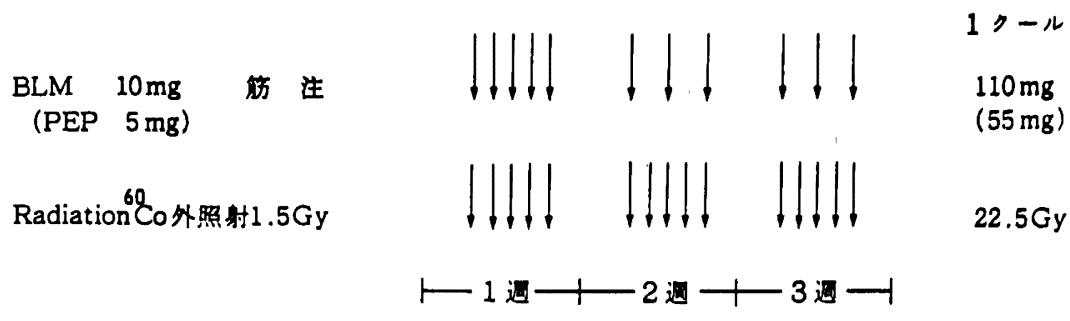

图 1 併用方式

衰 1 奶象症例

\begin{tabular}{|c|c|c|c|c|c|}
\hline & $\mathrm{T} 1$ & T2 & T3 & $\mathrm{T} 4$ & 㖕 \\
\hline 下額肉肉 & 1 & 5 & & 4 & 10 \\
\hline 煩 粘 膜 & & 1 & & 3 & 4 \\
\hline 口底 & & 1 & & 1 & 2 \\
\hline 舌 & & & & 2 & 2 \\
\hline 計 & 1 & 7 & 0 & 10 & 18 (例) \\
\hline
\end{tabular}

類では, T1，1 例，T2，7 例，T4，10 例であった（表 1).なお，下頻雪肉癌における T4 は，X線像で骨吸 収が歯槽部を越えて下颓骨体部に及んだ症例とした。

当科における放射線と BLM (PEP) の併用方式は园 1 亿示すごとく，3 週間に ${ }^{\circ 0} \mathrm{Co}$ 外照射 $22.5 \mathrm{~Gy}$ と BLM $110 \mathrm{mg}$ の同時併用を 1 クールとしている.PEPはBLM の約 $1 / 2$ 相当量 ${ }^{15)}$ であることから, $55 \mathrm{mg}$ を投与した. 併用療法終了後, 平均17.3日目に切除術を施行した。軟 組織部は治療前に腫敫の境界部にマーキング16)を行い, その周囲の 5〜10 mm の範囲を含めて切除した．下䫑骨 の切除は，各種 $\mathrm{X}$ 線像により骨吸收像を認めた症例では 安全域を十分に設けて行い，骨吸収像を認めなくても畽

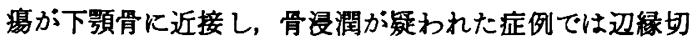
除を行った，したがって，辺縁切除例は11例，区域切除 例は 7 例であった。いずれの症例も切除した下買骨は照 射範囲内であった。

切除標本は10\%フォルマリン固定後, 軟組織と骨組織 を切離して, 軟組織部は半連続標本を作製し, 骨組織は 小さなものでは X線的な骨吸収像の中央部を，大きなる のでは数か所から，主として煩舌側方向にブロックを作 製して，脱灰標本とした。これらの標本は，通法に従い ヘマトキシリン・エオシンン染色を施し，検鏡した，組織 学的検索は腫浧実質の变化を中心に観察し, 治療効果の 組織学的な判定は大星・下里の分類 ${ }^{17}$ に従った.

なお，組織学的検索に先立ち，骨吸収の範囲ならびに 様式についてX線学的分析を行った. 垂直的な吸収範囲 について，有歯部では歯槽部，下䝷管上方部（下䫛管上

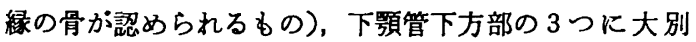
した. 無歯部では, ある程度歯槽部が残存していると判

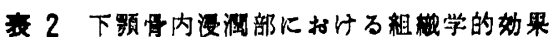

\begin{tabular}{|c|c|c|c|c|c|c|}
\hline \multirow{2}{*}{$\mathrm{T}$ 分類 } & \multicolumn{5}{|c|}{ 組端学的奻果（下里の分類） } & \multirow{2}{*}{ at } \\
\hline & $\mathbb{N}$ & III & II $\mathbf{b}$ & II a & I & \\
\hline $\mathrm{T} 1$ & & 1 & & & & 1 \\
\hline $\mathrm{T} 2$ & & & 2 & & 2 & 4 \\
\hline $\mathrm{T} 4$ & 1 & 1 & 2 & 3 & 2 & 9 \\
\hline 計 & 1 & 2 & 4 & 3 & 4 & 14 (例) \\
\hline
\end{tabular}

断した症例では，有歯部に準じて，下頻管上方を二等分 し，上半分を歯槽部，下半分を下顥管上方部とした，歯 槽部の残存がないと判断した症例では，下䫑管上方部， 下類管下方部に大別した。 また癌の浸潤発育の様相は， 辺绿部におけるX線的な吸收様式に着目し，平滑なるの を erosive type，不整なるのを invasive type に分類し た.

\section{結果}

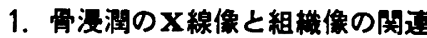

X線的に骨吸収像が認められなかった症例は 5 例で, 13例は骨吸収像が認められた。吸収範囲は，歯槽部 4 例， 下頻管上方部 7 例，下額管下方部 2 例であった．吸収様 式は, erosive type 4 例, invasive type 9 例であった. 組織学的には，18例中14例に骨浸潤が認められた。 X線 的に骨吸収像を認めた13例は，いずれも病理組織学的に 骨浸潤が認められ， $\mathbf{X}$ 線的に吸収像が認められなかった 5 例中 1 例で歯槽部滑髄内浸潤が認められ，4 例は組 織学的に骨浸潤が羿められなかった。

\section{2. 骨漫潤部の組穖学的効果}

病理組織学的に下顎骨浸潤が認められた14例のうち2 例は皮質骨に限局し，12例は歯槽部あるいは頓舌側の皮 質骨が破壊され，骨髄内に浸潤していた。骨浸潤部の組 織学的効果は, 大星・下里の分類に従い, Grade（以下 G. と略す) IV 1 例， G. II 2 例， G. II b 4 例， G. II a 3 例, G. I 4 例であった（表 2 ).

良好な効果が認められた G. IV， III，II b の 7 例を表 了に示す，いずれの症例も併用療法の前後において， $\mathrm{X}$ 


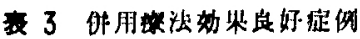

\begin{tabular}{|c|c|c|c|c|c|c|c|c|c|c|c|c|}
\hline \multirow{3}{*}{ 症例 } & \multirow{3}{*}{$\begin{array}{l}\text { 源発徼 } \\
\text { 部位 }\end{array}$} & \multirow{3}{*}{ 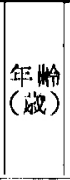 } & \multirow{3}{*}{$\mathrm{T}$ 分粗 } & \multirow{3}{*}{$\begin{array}{l}\text { BL.M } \\
\text { (mg) }\end{array}$} & \multirow{3}{*}{$\begin{array}{l}\text { (ill'(') } \\
\text { (liy) }\end{array}$} & \multirow{3}{*}{ 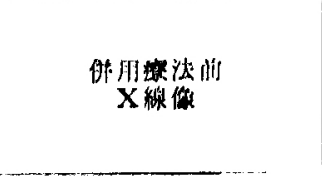 } & \multirow{3}{*}{ 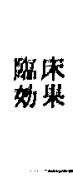 } & \multirow{3}{*}{ 組筇的 } & \multicolumn{4}{|c|}{ 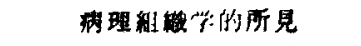 } \\
\hline & & & & & & & & & \multicolumn{3}{|c|}{ 近的漫洞部 } & \multirow{2}{*}{ 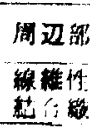 } \\
\hline & & & & & & & & & 線維住 & 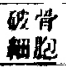 & 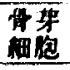 & \\
\hline 1. & 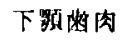 & 64 & $\mathrm{~T} 1$ & 75 & 23.0 & $(-)$ & C:R & 而 & H & - & H & - \\
\hline 2. & 下颔栍肉 & 61 & $\mathrm{~T} 2$ & 110 & 22.5 & (invasive) & $\mathbf{P R}$ & II $\mathrm{b}$ & W & - & $H$ & + \\
\hline 3. & 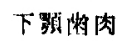 & 39 & $\mathrm{~T} 2$ & 190 & 40.5 & (crosive) & $(\mathrm{R}$ & II $\mathbf{b}$ & $H$ & + & - & + \\
\hline 4. & 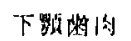 & 76 & $\mathrm{~T} 4$ & 75 & 22.5 & 下影管 1: J部（invasive） & ( $\mathrm{K}$ & II $\mathbf{b}$ & HH & - & + & - \\
\hline 5. & 卜紫顾性肉 & 69 & $\mathrm{~T} 4$ & $33 p$ & 22.5 & 下颗管卜方部 (invanive) & PR & II & $\mathrm{HH}$ & - & H & + \\
\hline 6. & 下颗嵝肉 & 70 & $\mathrm{~T} 4$ & $55 \mathrm{P}$ & 19.5 & ト颔管上掊（invasive） & PR & Il b & H & - & $H$ & - \\
\hline 7. & 烦 粘 謨 & 68 & 14 & $51 \mathrm{P}$ & 37.5 & 下颗管上力部 (invasive) & (:R & il & Hit & - & + & + \\
\hline
\end{tabular}

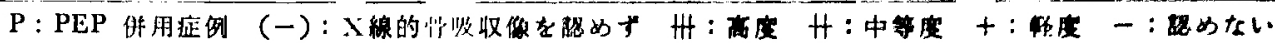

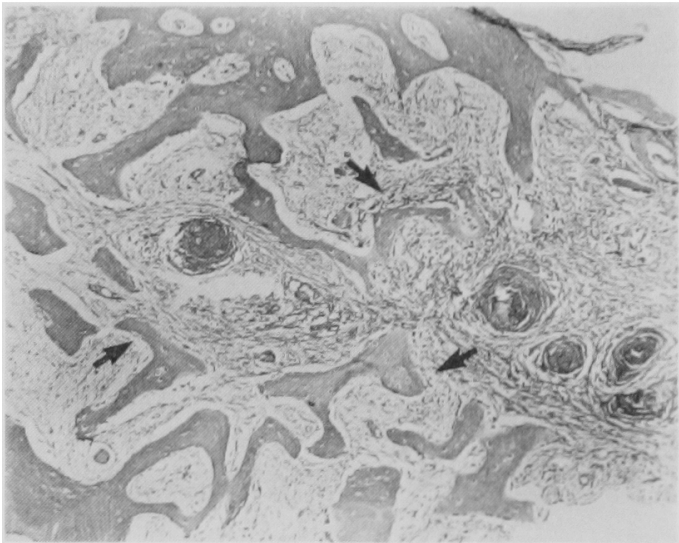

写真 1 症例 6 ：骨新生（矢印）恔性崩填した病 胞䉾の周囲に形成され，骨芽細胞の出現か; 高度に認められる（H-E 染色， $\times 80)$ 。

線的な骨吸収像における変化を認めなかった。

病理組織学的所見は，腫瘍の浸潤による皮質骨や海䄸 骨の破壊部では著しい線䧽性結合織の增生が認められ た.その内部には変性壊死をきたした癌胞巣が認めら れ，G．IIb 症例では生活癌細胞はごくわずかに残存して いた，破骨細胞は 1 例で生活癌胞米に近接した骨面に䶃 められたにすぎなかった，骨新生は6 例に認められた。 骨新生は破壊部辺縁の既存骨より連続して形成された り，変性崩壊した癌胞栄を取り囲むように形成され，骨 芽細胞の出現が高度に弪められた（写吉1）。また炎应 性細胞浸潤は軽度で新生骨の周囲にみられた。病巣周囲 の海綿骨では，多くの症例は線維性結合織の增生が軽度 にみられたが，一部の症例では線稚化を認めず，脂肪咀 のままであった。なお，併用㞠法後のX線像では骨新生 を示唆する所見は認められなかった。

ここて，代表的な症例 5 を示す，下顗畨肉癌 $\mathrm{T} 4$ 症例

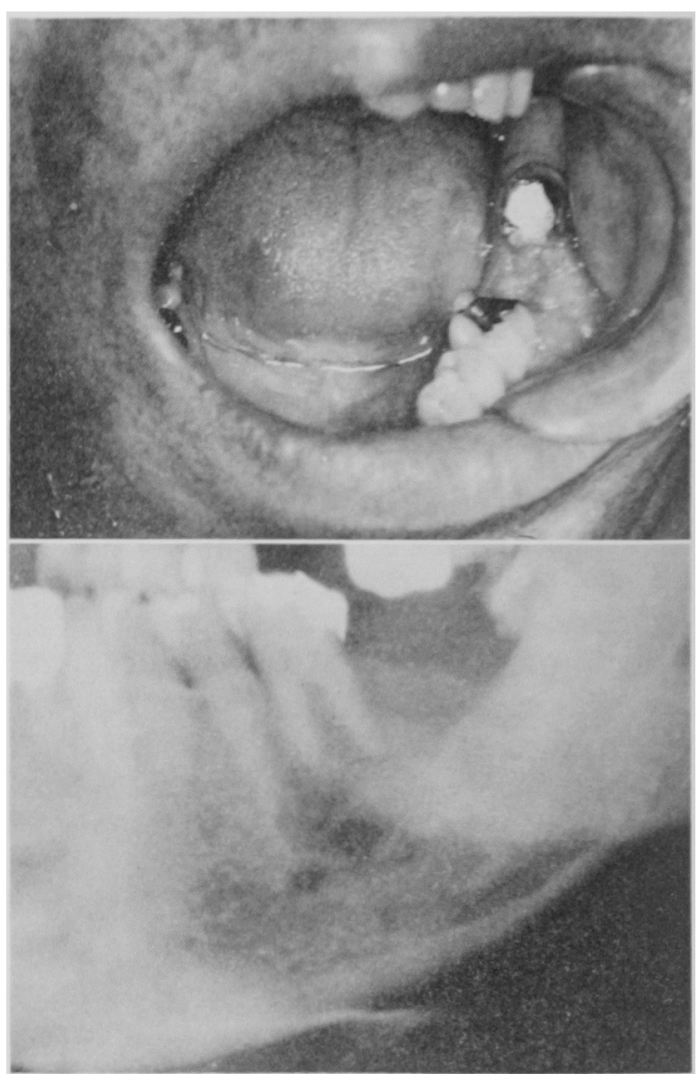

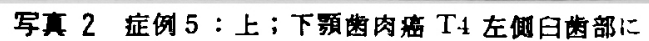

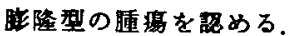

下; 下额管下方部, invasive type のX線的骨吸収像を認的る。

で，下顎管下方部，invasive type のX線的骨吸収像を認 め（写真 2)，下頡骨区域切除を行った。切除した下顎 骨では，下䫇管上縁にいたる骨破壊がみられ，同部は線 


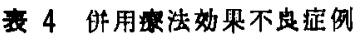

\begin{tabular}{|c|c|c|c|c|c|c|c|c|c|c|c|c|}
\hline \multirow{3}{*}{ 症例 } & \multirow{3}{*}{$\begin{array}{l}\text { 原笔巣 } \\
\text { 部 位 }\end{array}$} & \multirow{3}{*}{$\begin{array}{l}\text { 年. } \\
\text { (战战) }\end{array}$} & \multirow{3}{*}{$\mathrm{T}$ 分類 } & \multirow{3}{*}{$\begin{array}{l}\text { BLM } \\
(\mathrm{mg})\end{array}$} & \multirow{3}{*}{$\begin{array}{l}{ }^{60} \mathrm{Co} \\
\text { (Gy) }\end{array}$} & \multirow{3}{*}{$\begin{array}{c}\text { 旰用蟟法斺 } \\
\text { X線像 }\end{array}$} & \multirow{3}{*}{$\begin{array}{l}\text { 區床 } \\
\text { 奻果 }\end{array}$} & \multirow{3}{*}{ 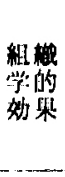 } & \multicolumn{4}{|c|}{ 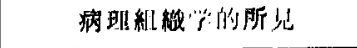 } \\
\hline & & & & & & & & & \multicolumn{3}{|c|}{ 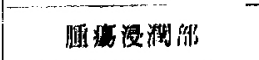 } & \multirow{2}{*}{ 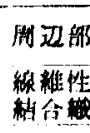 } \\
\hline & & & & & & & & & 線䊒性 & 佊挪 & 将果 & \\
\hline 8. & 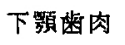 & 65 & $\mathrm{~T} 2$ & 120 & 22.5 & $(\operatorname{crosive})$ & $\mathrm{PR}$ & I & + & W & - & - \\
\hline 9. & 下箱萪肉 & 54 & $\mathrm{~T} 2$ & 110 & 22.5 & (erosive) & MR & I & $H$ & H & - & $H$ \\
\hline 10. & 下顎橉肉 & 65 & $\mathrm{~T} 4$ & 120 & 22.5 & 下敫管上方部 (erosive) & MR & I & + & + & + & + \\
\hline 11. & 頓 粘 瞙 & 49 & $\mathrm{~T} 4$ & 110 & 22.5 & 下熲管上少部 (invasive) & ( 'R & II $\mathbf{a}$ & H & + & + & + \\
\hline 12. & 底 & 51 & $\mathrm{~T} 4$ & 110 & 22.5 & *下顎管上少部 (invasive) & MR & II $\mathbf{a}$ & H & + & + & - \\
\hline 13. & 舌 & 59 & $\mathrm{~T} 4$ & $45 \mathrm{P}$ & 15.0 & 下頭管上方部（invasive） & MR & Il a & H & W & - & - \\
\hline 14. & 舌 & 64 & $\mathrm{~T} 4$ & $75 \mathrm{P}$ & 30.0 & 下顎管下方部（invasive） & $M R$ & I & + & $H$ & - & + \\
\hline
\end{tabular}

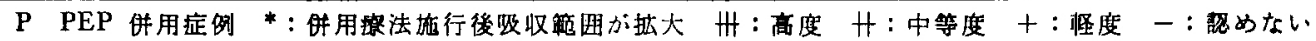

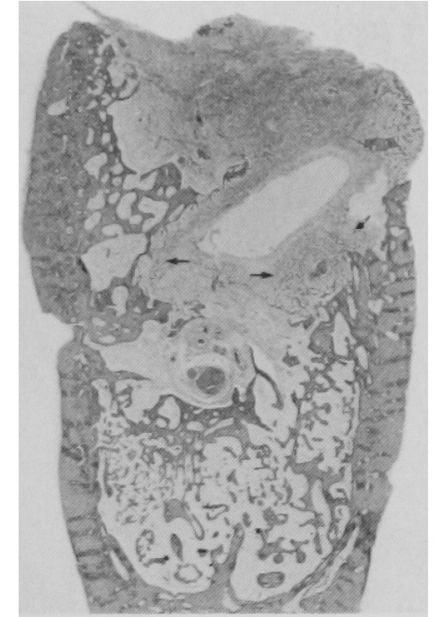

写真 3 症例 5 : 骨破壊は高度で,下 影管に及ふ。線維性結合織の 增生が著明で，既存の骨に近 接して骨新生（矢印）を認め る(H-E 染色, $\times 1)$.

維性結合織で置换されていた，変性壤死した癌胞单が一 部で認められ，生活癌細胞はみられず，組織学的効果は G．IIIであった（写真 3)，骨新生は既存の骨梁や皮質 骨に近接して諗められたが，一か所で変性崩壊した癌胞 巣を取り囲み，細い樹枝状の骨新生が観察された（写直 4).

つぎに効果が不良であったG．II a，Iの 7 例を表 4 に 示す.このうち，G，Iａ１例とG，Iの 2 例は併用 療法後にX線的に骨吸収像の抬大が認められた。

病理組織学的には, 骨破壊部では, 癌胸巣がその大部 分を占め，一部の症例では癌胞巣が線維性結合織の中に 分散していた，破壊された骨面には，不整な吸収窩と多

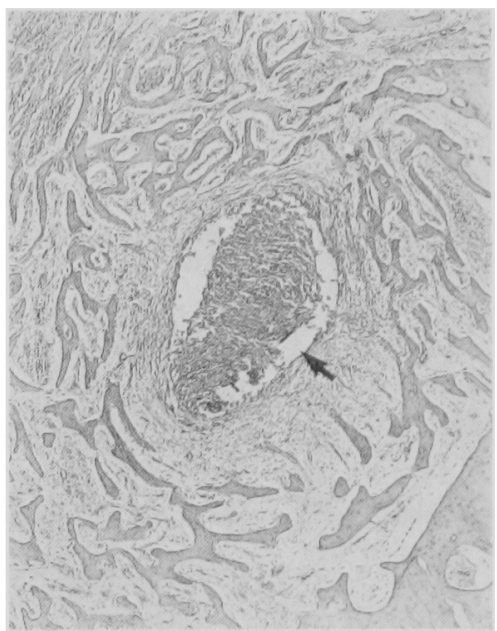

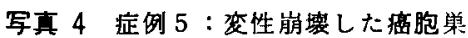
(矢印)の周囲に樹枝状の骨新 生を認める (H-E 染色 $\times 27)$.

数の破骨細胞が認められた，骨新生は一部の症例で認め たが，奻果良好例に比べ少なかった．同一切片において る癌胞巣の変性が高度な部分では骨新生を認めたが，生 活癌胞单の周辺ではみられなかった（写直 5).

3. 組蟣学的効果 G. II b 症例における生活癌細胞残存 部位

骨浸潤症例に本併用療法を施行し，どの部位に生活癌 胞巣が残存しやすいかを検討する目的で，小範囲に限局 して生活癌胞巣が牫存した G. II b 4 症例について, 検索を行った，各症例に拈ける癌胞巣の残存部位は图 2 のごとくで， 1 例は粘膜部から連続して隶槽部まで残存 し, 他の 2 例は生活癌細胞は軟組織部では認めす。，骨浸 潤部に残存が認められた，残りの 1 例は，皮質骨の外側 表層に限局して浸潤を認めた症例て，骨吸収面に近接し 


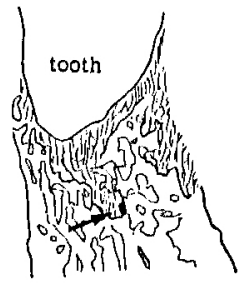

静: 例 2:

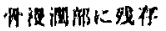

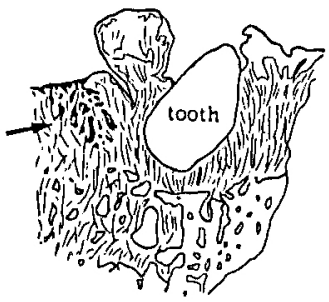

症例 4:

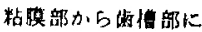

残存

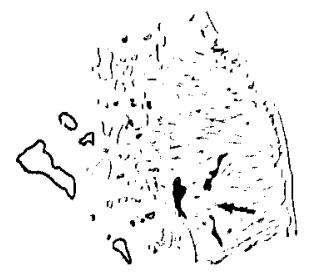

幽 3:

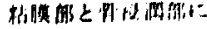

棵位。

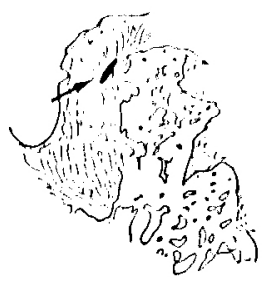

䤠例 6:

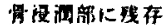

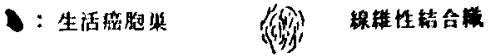

图 2 Grade II b 症例の腫埸残存部位

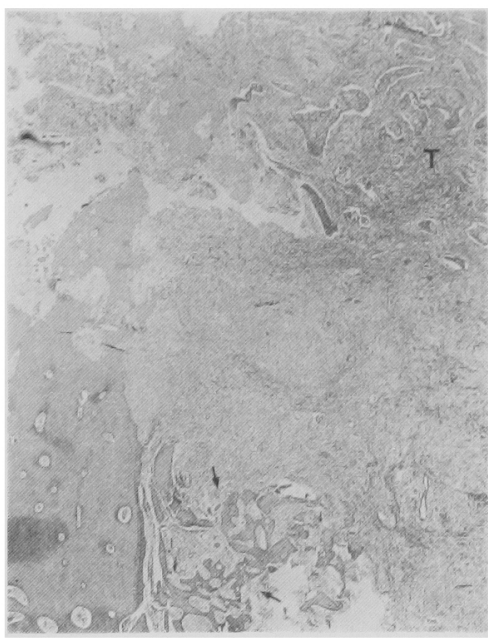

写真 5 症例12：骨新生（知印）壮生 活癌胞栄 $(T)$ から離れて認 められる(H-E 染色, $\times 20)$.
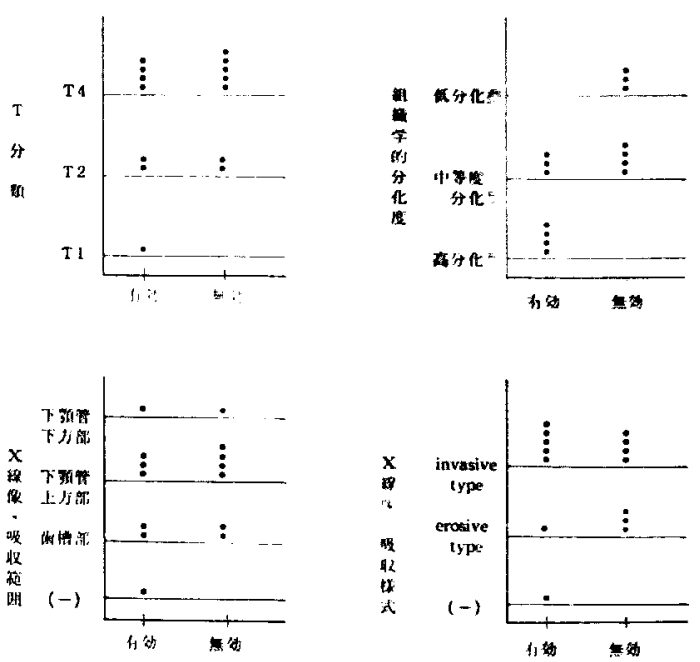

図 3 臨床的病理組織学的所見々組織学的效果 


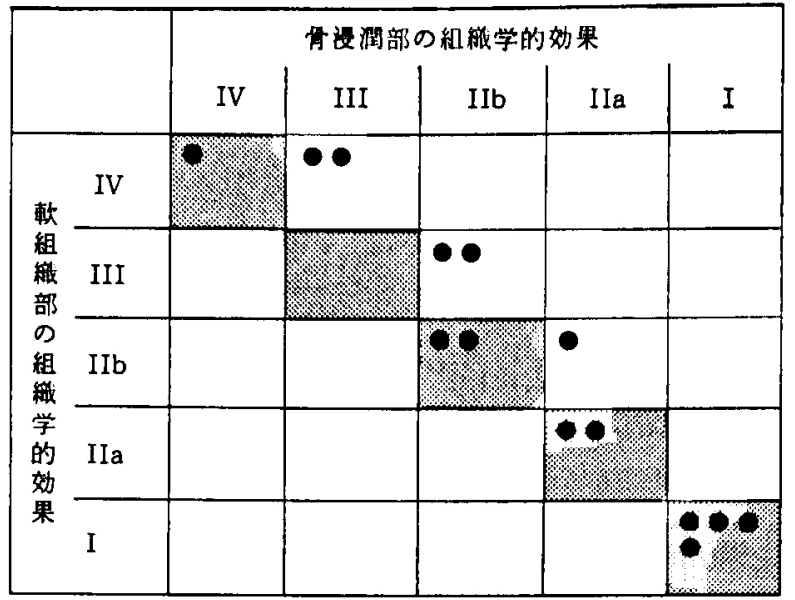

図 4 聫組織部之骨浸潤部の組織学的奻果の比校

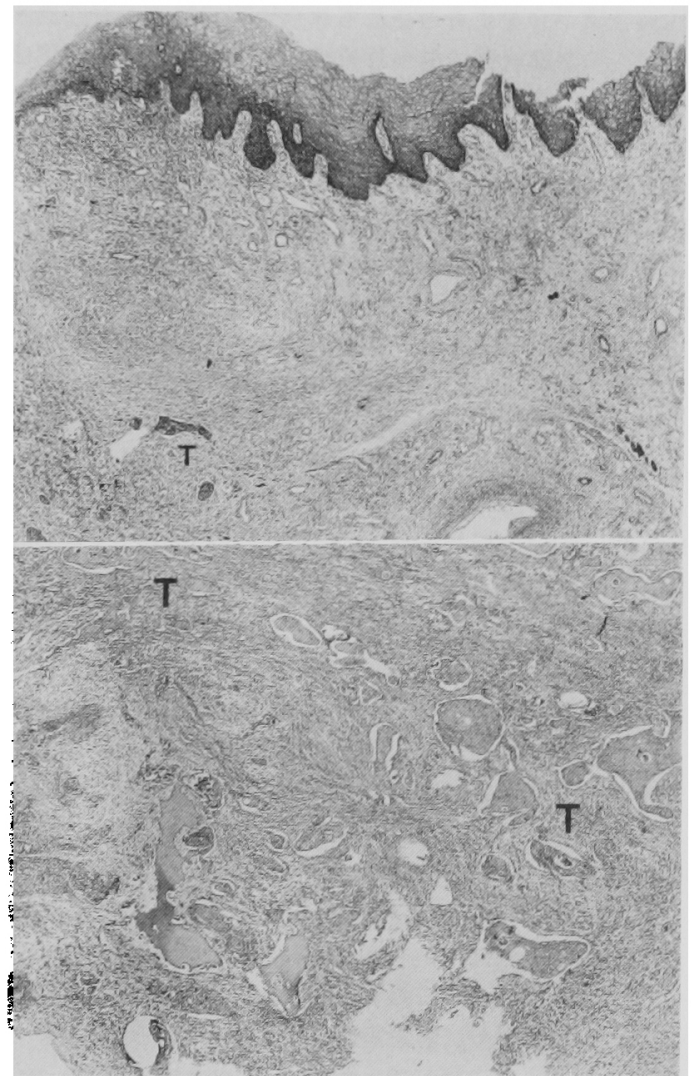

写真 6 症例 $12:$; 軟組樴部は線䊒性結合織の中 にわずかに生活癌胞巣 ( $\mathrm{T}$ ) を認める(H-E 染色， ×27)

下; 骨浸潤部では多くの生活癌胞 米 (T) を認める(H-E 染色, $\times 27$ )
て生活痖細胞が認められた.

4. 組織学的効果亡 $\mathbf{T}$ 分類, $\mathbf{X}$ 線的骨吸収像, 組䋘学 的分化度との関連

組織学的効果かＧ，IV，II，II b を有奻， G．II a， I を 無効として，奻果の良否と $\mathrm{T}$ 分類， $\mathrm{X}$ 線的骨吸収像，治 療前の生検標本に拈ける組織学的分化度上の関連を顺討 した.これらのらち，組緎学的分化度との関連が示唆さ れ，高分化型はいずれる有效例であり，逆に低分化型は いずれも無効例であった，中等度分化型では7例中 3 例 が有效例であった，T分類ならびにX線的骨吸収像との 関連は明らかではなかった（因了）.

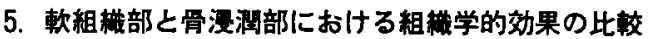

同一症例について軟組織部之骨漫潤部の組織学的効果 を比較すると，9例は両者に大きな差はなかったが，5 例は骨浸潤部における組織学的効果が軟組織部よりも1 grade 低かった（因 4 ，写竞6）.

\section{6. 原発䉾の再発}

原発巣の再発は 4 例に認められた，初診時のX線的な 骨吸収範囲は，畨槽部 $1 / 4$ 例，下顎管上方部 $2 / 7$ 例，下 罰管下方部 $1 / 2$ 例であった。吸収様式は, erosive type 1/4 例, invasive type $3 / 9$ 例であった。初回治療の切除 術式は，辺縁切除を行った $2 / 7$ 例，区域切除を行った $2 / 7$ 例に認められた。組織学的効果は， 2 例が G，Iで あり，他の 2 例は $\mathrm{G}$ II a とG. IIbであった（表 5 ）。

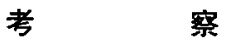

\section{1. 下顎骨漫潤症例に対する併用療法の有用性}

下顎菊肉癌に対する放射線とBLM の併用療法に関し て，真崎ら ${ }^{12)} は{ }^{60} \mathrm{Co} 30 \mathrm{~Gy}$ と BLM $90 \mathrm{mg}$ を基準にし た約 100 例の臨床効果は，T1，T2 症例で CR 率70\%， T3，T4症例でも51\%で，故射線照射単独療法に比較し 
5 再努招侧

\begin{tabular}{|c|c|c|c|c|c|c|}
\hline \multirow{2}{*}{ 症例 } & \multirow{2}{*}{ 部 } & \multicolumn{2}{|c|}{$\mathbf{X}$ 線的情吸収像 } & \multirow{2}{*}{ 切除㣲式 } & \multirow{2}{*}{ 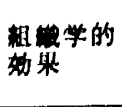 } & \multirow{2}{*}{ 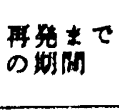 } \\
\hline & & 笵 & 㥞 式 & & & \\
\hline 4. & 下颗肉肉 & 下暊管上方部 & invasive & 记耧切除 & II $\mathbf{b}$ & $5 \mathrm{~m}$ \\
\hline 9. & 下顆米肉 & 曲槽部 & erosive & 辺鲜切除 & I & 1 y $1 \mathrm{~m}$ \\
\hline 12. & & 下頑上部 & invasive & 区域切除 & II a & 1 y $4 \mathrm{~m}$ \\
\hline 13. & 舌 & 下雅管下办部 & invasive & 区域切除 & 1 & $3 \mathrm{~m}$ \\
\hline
\end{tabular}

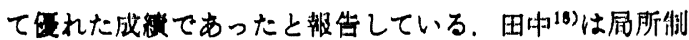

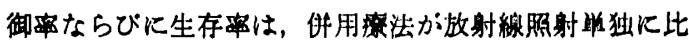
べ優れていたと述べている，他の報告においてる，下顆 骨漫泪症例に対する併用療法の評価は比校的良い上5て

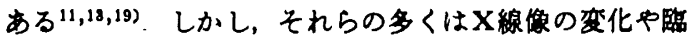
床経過についての検时であり，病理組樴学的な覞点から 論した報告は少ない，そこで，著者らは系絴的に放射線 と BLM (PEP) 同時併用暴法を行った症例の5ち，組 樴学的に骨漫潤が確かめられた14例について，病理組織 学的梌索を行った。

本併用療法は，骨浸潤部に腫場の残存を認めないG. VV， II が 3 例 $(21.4 \%) ，$ 此交的効果が 良好であると判 断された G. II b 以上が 7 例 (50.0\%) であった。これ ら 7 例のらち 4 例は，X線像て歯槽部を越えて骨吸収像 が認められた症例であった。田中田)は下額齿肉癌に対し て，照射線量 $29.5 \mathrm{~Gy}$ と BLM $85 \mathrm{mg}$ の併用で，組䋞 学的効果かiG. IN 11/26 例，G. II b 以上 $20 / 26$ 例であ ったと述へている。

下䫓骨浸润症例飞対与る放射線照射単独中 BLM 単独 投与後の組織学的な効果に䦎して，詳細な報告は少な い，放射線単独照射の場合は，戸塚ら》は種々の程度の 癌細胞の变性壊死あるいは線維化や骨新生を認めたが， 40 65 Gy の線量ではその効果は表層部にとどまってい たと述べている．BLM 単独投与の場合は，大成20)は盾 瘍の隆起部の脱落消失により著しく腫瘍が縮小したかに みえても，骨浸潤部に残存する癌細胞の変性は軽度で， BLM 効果の限界を述へている．本併用療法では約半数 の症例に対して比較的良好な組織学的効果が得られ，有 効な治療法であると思われる，さらに効果の良否に関与 する因子について恰討したか，それについては後述す る.

また今回，軟組織部と骨浸潤部の効果を比較したとこ ろ，5例は骨浸潤部の組織学的効果が軟組織部のそれよ り 1 grade 低く，その5ち大星・下里分類で G. II b と 判定した 2 例は，軟組織部では生活癌細胞を認めない が，骨漫潤部でその残存が認められた。したがって，た とえ軟組織部の効果が良好であっても骨浸潤部には癌細 胞の残存する可能性があり，このことは骨の切除範囲を 設定する上で考虑すべきであると考えられる.

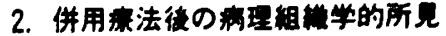

われわれが行った併用器法では，奻果が良好と判定し

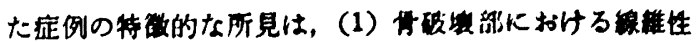

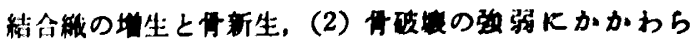

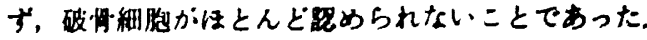

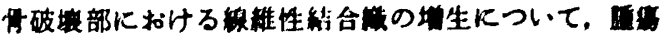

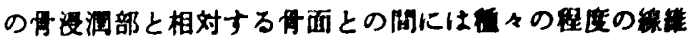

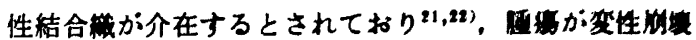

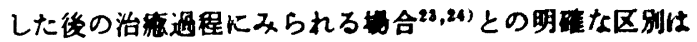

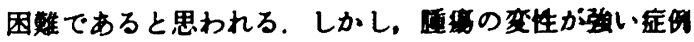

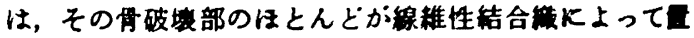

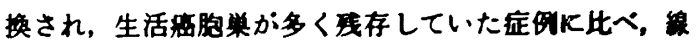
䊒性結合啭の增生が高度であった。 また，その内部に忙 変性壤死した我胞紧が混在して認められた。 したがっ

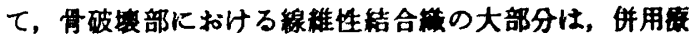

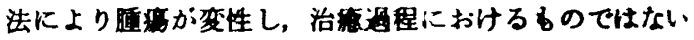
かと考えられる。

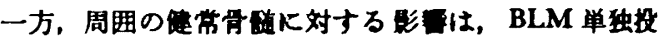
与に成する報告はみられないか，照射線量が $60 \mathrm{~Gy}$ 以上

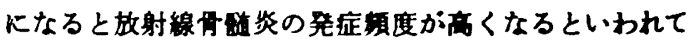

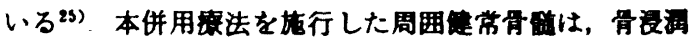

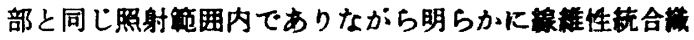
の增生程度が異なり，侱度であった。この点は，骨漫洞 が認められなかった症例でる同粔であった。したがっ て, 照射線量 $22.5 \mathrm{~Gy}$ と BLM $110 \mathrm{mg}$ (PEP $55 \mathrm{mg}$ ) を基本とした本併用方式では，腱常骨照への障害は整度 であると推察され，副作用の発現や再建に宗して有利で あると考えられる．実祭に重第な副作用の発現や，再建 において特に問題となった症例はなかった。

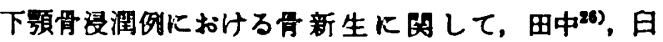

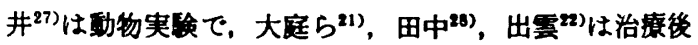
の人体下預骨について報告しており，骨新生は盾岛浸洞 部周辺の骨鲑部や皮質骨外例面に形成されることが多 く，骨破壞部には概してその甚が少ないよ5である。今 回の梌索に打いても，生活我細胞が多く残存した症們で は，骨破壊部の骨新生はわずかであった。また放射線の 影䇾による骨新生す考虑されねばならないが，照射初期 に怡骨吸収像を認め，3か月以阵に骨新生を認めるよ5 になるといわれている29)。対象症例では，併用療法の開 
始から手術までの期間は1〜2か月なので，放射線の影 整による骨新生は少ないるのと推察される，椐山ら BLM 単独投与によって連疗が消失し，骨新生を綛めた 症例を報告し，形成部位が骨破墒部を被得充呮しようと する所見を呈していること，骨形成部位ては疝の壤死残 骼栄を認めてる，生活癌細胞は钼察し得なかったことよ り攸復性の骨新生であろらと述べている，今回の検索で

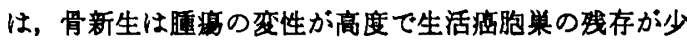
ない症例や，同一症例です生活㾞胞紧から崔れた部位で 認められた。また骨破壞部において，不整な骨吸収面か ら連続して形成されたり，变性崩壤した痖胞紧を取り囲 む所見，あるいは破骨細胞が認められなかったことなど より答復性の骨新生ではないかと考えられた。

一般に腫暍の浸洞によろ骨吸収棣式に闺しては，破骨 細胞を認める場合と破骨細胞は恋めず，腫緆組織そのも のが骨面に接触して吸収が進行する揚合があるといわれ ている ${ }^{31)}$. 扁平上皮癌の下額骨浸潤症例では, 吸収された 骨面に破骨細胞の出現を認めるとの報告が多い21,28,27). 対象症例の5ち生活癌胞笨の残存が多い症例では，不整 な骨吸収面に多くの破骨細胞を諗めた。

放射線照射が破骨細胞に及ぼす影霎について, O’brien ら゙)は放射線照射により破骨細胞の反応を減じることは なかったと述へている，したがって，組織学的効果が良 好であった症例では腫瘍が変性消失した結果，修復機転 が活発となり，破骨細胞の出現がほとんど認められなか ったのではないかと考えられる.

\section{3. 組織学的効果に関連する因子}

前述したように, 約半数の症例は組織学的効果が良好 であった，そこで，効果の良否に関連する因子を検討し た結果, 組織学的分化度が高分化型は有効で，低分化型 は無効であった．当科において，本併用療法を施行した 口腔粘膜扁平上皮癌82例のすべてにおいても同様の結果

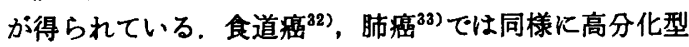
の症例に有効であったとする報告が多いが，口腔癌に対 する併用療法の組織学的効果に関して, 分化度との関連 について検索を行った報告は，他には大山ら ${ }^{34)}$ の報告を みるにすぎない.

従来， $\mathbf{X}$ 線的な骨吸収像と予後との関連がいわれてい

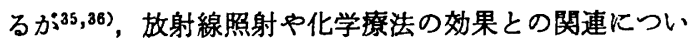
ては報告が少ない，そこでX線的な吸収範囲や吸収様式 と組織学的効果との関連を検討したが，明らかな関連は 見出せなかった。

\section{4. 下額骨漫潤症例に対する本併用療法の意荽}

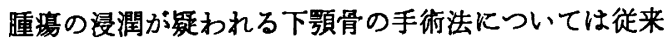
より種々の論議がなされているが，一般には下顎骨区域 切除術あるいは半側切除術が適応とされている ${ }^{3,36)}$. 最 近は再建術が進歩し，広範用な切除が行われているか， 逆に辺緑切除術の適応についても検討がなされてい

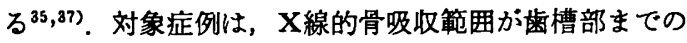

症例中下顒管上方部の症例の一部に辺緑划除を施行し， 7 例中 5 例は再発がみられなかった，したがって，辺䋧 切除術が遮応となる症例る比较的多いのではないかと思

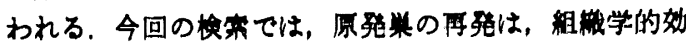
果が乏しい症例に多かったが，併用毒法の效果と奵除術 式との闯速については明確な結眮は見い出せなかった。 本併用痖法では，良好な組織学的奻果を行られた症例に おいても，生活掂胞学が具没润部に残存していたことを 考虑すれば，やはり従来どおりのX線的吸収筑囲を十分 に含んた切除が必要のよ5である。しかし，術前治度を 行わない坦合之同じ切除簀围でる安全城が広く得られる ことは，本併用察法の意辀は十分にあると考えられる。

また生活㾇細胞を認めなかった G，II， IV 例は，切除を 行わずに本併用㾯法たけで制御し得る可能性があると思 われた.

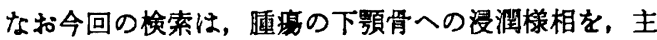
として垂直的な断面から行った. 今後は，O'brien ら'

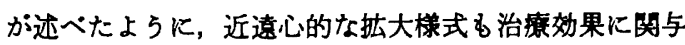
する1つの因子として，検討する必要があると思われ る.

結

站

1976年より1985年までに九州大学梅学部附属病院口腔 外科で, 放射線と BLM (PEP) の同時併用療法を施行 した口腔粘膜扁平上皮癌一次症例のうち，下頞骨切除を 行った18例について病理組織学的な検索を行い, 本併用 療法の術前治療としての意義について検討した。

1. 18 例中 14 例は, 病理組織学的に隀瘏の下顥骨浸潤 が珰められ，組織学的効果は大星一下里の分類に従い, G. IV 1 例, G. II 2 例, G. II b 4 例, G. II a 3 例，G. I 4 例であった.

2. 組織学的な効果が良好であった症例では，骨破壊 部における線䧽性結合織の増生が著明で, 破骨細胞は非 常に少なく，修復性骨新生が認められた。

3. 治療前の組織学的分化度が高い症例は，組織学的 効果が良好であった。 X線的骨吸収像と組織学的効果と の関連は明らかではなかった。

4. 骨浸潤部の組織学的効果を軟組織部のそれと同一 症例に拈いて比較すると，9例は同等であったが， 5 例 は骨浸潤部が 1 grade 低かった。

5. 今回の検討より, 効果が良好な症例でも，X線的 な骨吸収像を十分に含む切除が必要であると考えられ た.しかし，術前治療を行わない場合と同じ切除範囲を 設定しても安全域が広く得られ, 本併用療法は術前治療 としての意義があると思われた。

6. 本治療法による健常部組織の障害は, 軽度であっ た. 
本論文の要百は第41回日本口些科学全総会（1987，束 京にに括いて発次した。

\section{引用文 塥}

1) Modlin, J. and Johnson, R.E.: The surgical treatment of cancer of the buccal mucosa and lower gingiva. Am J Roentgenol 73: 620-627 1955.

2) Swearingen, A.G., McGraw, J.P., et al. : Roentgenographic pathologic correlation of carcinoma of the gingiva involving the mandible. Am J Roentgenol 96: 15-18 1966.

3) O'brien, C.J., Carter, R.L., et al.: Invasion of the mandible by squamous carcinomas of the oral cavity and oropharynx. Head \& Neck Surg 8: 247-256 1986.

4）直松度：口腔瘦の故射線治瘄。日医故線会誌 37: 261-285 1977.

5) Byers, R.M., Newman, R., et al.: Results of treatment for squamous carcinoma of the lower gum. Cancer 47: 2236-2238 1981.

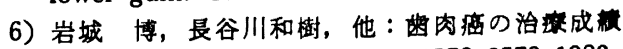
に関する模討。 日外誌 29：2578-2579 1983.

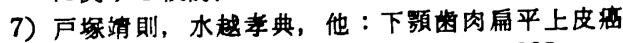
の臨床的研究. 日外誌 31：36-51 1985.

8）作田正義, 類田純一郎, 他: 頭頸部扁平上皮瘱 の再発に咸する研究。日外誌 26:353-360 1980.

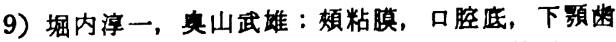

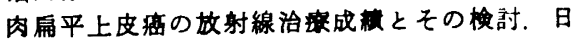
医故線会誌 34：739-751 1974.

10) 大関俉, 网本学, 他: 口腔满の到部リンハ 節転移栄に対す万故射線 - Bleomycin 併用家法 の奻果, 日癌治誌 21: 664-670 1986.

11）古川哲夫，大野揘八郎，他：口腔瘦に対する Bleomycin 使用による治症経㯺。特に非手综例 について，日口外誌 20：124-135 1974.

12）真崎規江，池田饭，他：放射線治瘄とブレオ

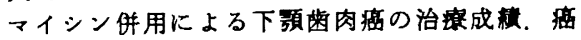
の臨 35: 123-128 1986.

13）清水谷公成, 川绮靖典, 他: 故射線とPeplo-

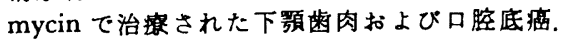
菌放 26: 144-147 1986 .

14) Harmer M.H.: TNM Classification of Malignant Tumors. 3 rd, UICC, Geneva, 1987, p 23-26.

15) Shakamoto, K., Komatsu, K., et al.: The in vitro and in vivo antitumor effects of pepleomycin alone or in combination with Radiation. Radiat Res 102: 224-231 1985.

16）田代英雄, 大関 悟, 他: 口腔瘦辺緑のマーキ ングの効用. 癌の臨 24: 1019-1022 1978.

17) Shimosato, Y., Obosi, S., et al.: Histological evaluation of effects of radiotherapy and che- motherapy for carcinomas. Jap J Clin Oncol 1: 19-35 1971 .

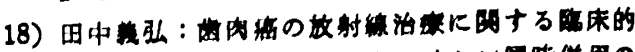

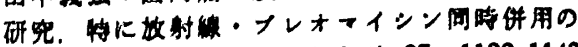

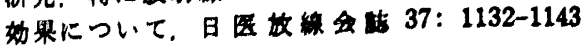
1977.

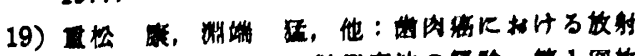

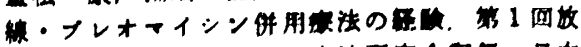

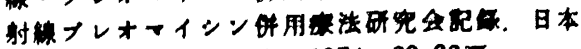

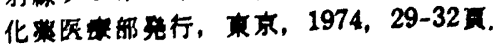

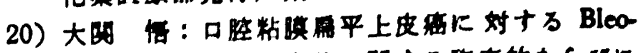

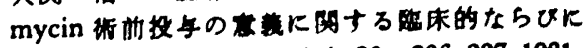

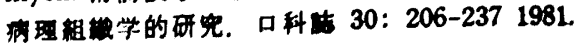

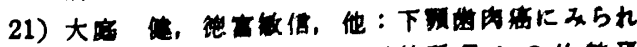

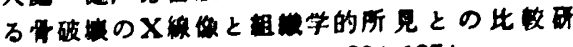

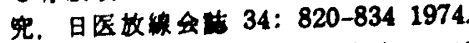

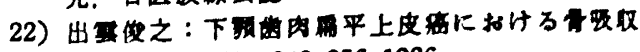

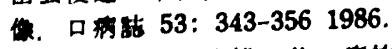

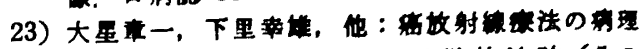

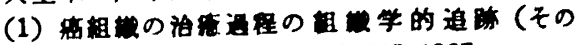
1). 医学のおゆみ 61: 618-625 1967.

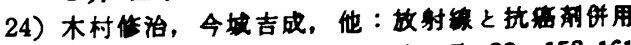

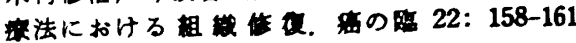
1976.

25) Lucks, D., and Sonis, S.T.: Dental management for cancer patients receiving head and neck radiation. Oral Cancer, Saunders, Philadelphia, 1984, p 138-141.

26）田中広一：我受间に上万骨反心に成与万研光。

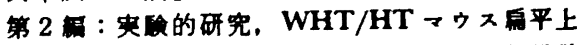

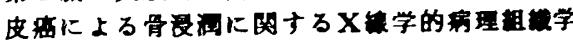
的研究. 日外他 25:769-777 1979.

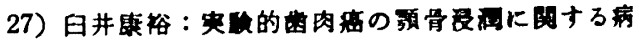

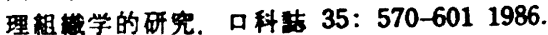

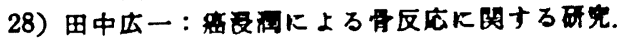

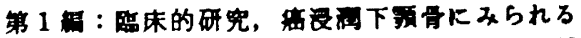
骨新生に网与る研究。日口外站 25：757-768 1979.

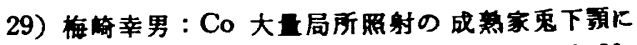

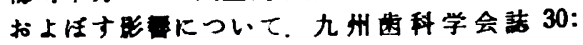
1093-1127 1977.

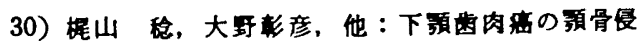

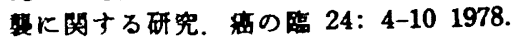

31）須田立堆，小讯英造，他：骨の科学. 第 1 服, 医蒋出版，東京，1986，240-241頁.

32）没勿克，唐讯和夫，他：食道盘に詨する合併 法法. 一故射線とブレオマイシンの併用による

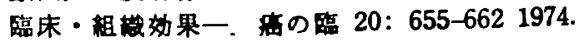

33）奥野武彦，木村攸治，他：肺盘における故射線 プレオマイシン併用腺法. 第 1 回放射線ブレオ マイシン併用度法研究会記绿，日本化薬医莫部 発行, 東京, 1974, 50-53面.

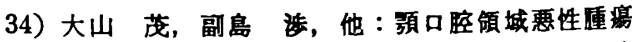
の臨床的研究.一第 2 報口腔离(扁平上皮病) に対する Peplomycinを主体とした化学瑔法に 
ついて一. 日口外誌 33: 753-759 1987.

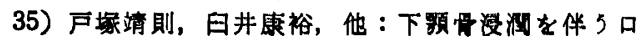

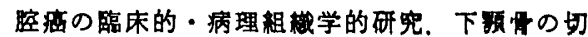
除籍囲について。日外誌 29: 811-828 1983.

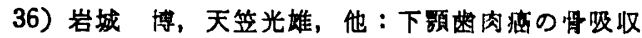

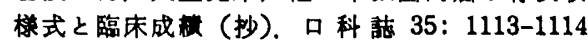

1986.

37) Wald, R.M. and Calcaterra, T.C.: Lower alveolar carcinoma. Segmental versus Marginal resection. Arch Otolaryngol 109: 578-582 1983. 